С.В. Годзь, В.М. Можаровський, Р.В. Пантюшенко

Центральний науково-дослідний інститут Збройних Сил Украӥни, Київ

\title{
ОПТИМІЗАЦІЇ РОЗПОДІЛУ НАВЧАЛЬНИХ ГОДИН КОМПЛЕКСНОЇ ПРОГРАМИ БОЙОВОЇ ПІДГОТОВКИ З'ЄДНАННЯ (ЧАСТИНИ) МІЖ СПЕЦІАЛІСТАМИ (ПІДРОЗДІЛАМИ) РОДІВ ВІЙСЬК
}

\begin{abstract}
Пошук можливих шляхів підвищення ефективності бойової підготовки (БП) військових формувань, як невід'ємної складової їх боєздатності, завжди був і залишається пріоритетним напрямом діяльності та першочерговим завданням командирів і штабів усіх рівнів. На думку авторів, одним із можливих иляхів забезпечення потрібного рівня навченості військових формувань є розроблення та запровадження в практику їх БП принципово нового нормативного документа - Комплексної програми бойової підготовки військового формування типу з'єднання (частина) сил оборони (КПБП). Розроблення КПБП має бути всебічно, зокрема науково, обтрунтованим. Проте в існуючих методиках оцінювання ефективності БП військових формувань, у тому числі ї̈ планування, використовуються зовсім різні методи дослідження залежності рівня навченості спеціалістів певної категорії (профілю) та підрозділів родів військ від кількості навчальних годин, які протягом певного періоду виділяються на їх підготовку. Існуючі методики не дозволяють здійснювати раціональний (оптимальний) розподіл навчальних годин між спеціалістами (підрозділами) родів військ для досягнення заданого рівня навченості з'єднання (частини) у цілому. Також иі методики не враховують (враховують частково) обмеження щзодо фінансування заходів БП та не передбачають комплексного підходу до забезпечення потрібного рівня боєздатності з'єднань (частин).

На думку авторів, нині виникла потреба у використанні методичного апарату, який би, враховуючи рівень фінансування БП, дозволяв визначати оптимальну кількість навчальних годин, а також здійснювати їх оптимальний розподіл між спеціалістами (підрозділами) родів військ для досягнення заданого рівня навченості з'єднання (частини) у ичілому. У пропонованій статті викладено основний зміст задачі оптимізації розподілу навчальних годин КПБП між спеціалістами (підрозділами) родів військ для досягнення заданого рівня їх навченості (лінійний варіант). Стаття є логічним продовженням попередніх публікацій за даним напрямом дослідження.
\end{abstract}

Ключові слова: бойова підготовка, планування бойової підготовки, комплексна програма бойової підготовки, математична модель, метод дослідження, задача оптимізації.

\section{Вступ}

Постановка проблеми. Одним із можливих шляхів забезпечення потрібного рівня навченості військових формувань (ВФ) є розроблення та запровадження в практику їх БП принципово нового нормативного документа - Комплексної програми бойової підготовки військового формування типу з'єднання (частини) сил оборони (КПБП), яка має стати важливим інструментом в діяльності органів управління (штабів) усіх рівнів [1-5].

Аналіз останніх досліджень і публікацій. В існуючих методиках оцінювання ефективності БП військових формувань, у тому числі іiі планування [6-9], використовуються зовсім різні методи дослідження залежності рівня навченості спеціалістів певної категорії (профілю) та підрозділів родів військ від кількості навчальних годин, які протягом певного періоду виділяються на їх підготовку. Існуючі методики не дозволяють здійснювати раціональний (оптимальний) розподіл навчальних годин між спеціалістами (підрозділами) родів військ для досягнення заданого рівня навченості з'єднання (частини) у цілому. Також ці методики не враховують (враховують частково) обмеження щодо фінансування заходів БП та не передбачають комплексного підходу до забезпечення потрібного рівня боєздатності з'єднань (частин).

Мета статті. Метою статті є викладення суті та основного змісту задачі оптимізації розподілу навчальних годин КПБП між спеціалістами (підрозділами) родів військ з'єднання (частини) для досягнення заданого рівня їх навченості (лінійний варіант). Стаття $є$ логічним продовженням попередніх публікацій за даним напрямом дослідження, зокрема [1-10].

\section{Виклад основного матеріалу}

Навчальний час $x_{i}$, який протягом періоду БП з'єднання (частини) буде виділятися на підготовку спеціалістів певної $i$-ї категорії (профілю) $x_{i}(i=\overline{1,4})$, наприклад механізованих $\left(x_{1}\right)$, танкових $\left(x_{2}\right)$, apтилерійських $\left(x_{3}\right)$, зенітних $\left(x_{4}\right)$ підрозділів омбр (отбр), обчислюватиметься з урахуванням мініміза- 
ції загальних фінансових затрат (“вартості”) $C$ щодо їх підготовки, але $з$ метою досягнення основної мети - рівня навченості $E\left(x_{i}\right)$ відповідної $i$-ї категорії спеціалістів, який би був не нижче потрібного

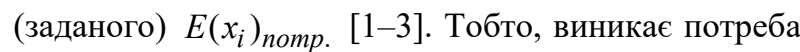
у відшуканні значень $n$ змінних $x_{1}, x_{2}, x_{3}, x_{4} \ldots, \cdot x_{n}$, які 6 доставляли екстремум функції $C=\sum_{i=1}^{n} c_{i} \cdot x_{i}$ за критерієм мінімуму фінансових затрат. У цьому випадку цільова функція (ЦФ) задачі лінійного програмування матиме вигляд:

$$
\begin{gathered}
C=c_{1} \cdot x_{1}+c_{2} \cdot x_{2}+c_{3} \cdot x_{3}+c_{4} \cdot x_{4}+\ldots .+ \\
+c_{i} \cdot x_{i}+\ldots+c_{n} \cdot x_{n}=\sum_{i=1}^{n} c_{i} \cdot x_{i} \rightarrow \min
\end{gathered}
$$

за таких умов-обмежень $g_{j}(j=\overline{1, m})$ :

фінансові ресурси (кошти) $C_{i}$, які необхідні для підготовки певної $i$-ї категорії спеціалістів 3 урахуванням запланованого для цієї категорії ресурсу навчального часу $x_{i}$, не повинні перевищувати виділених $C_{\text {і обм }}$ :

$$
C_{i} \leq C_{\text {і обм }}
$$

досягнутий рівень підготовки (навченості) $E\left(x_{i}\right) \quad i$-ї категорії спеціалістів має бути не нижче потрібного (заданого) $E\left(x_{i}\right)_{\text {nomp }}$ :

$$
E\left(x_{i}\right) \geq E\left(x_{i}\right)_{\text {nomp. }},
$$

де $x_{i}(i=\overline{1,4})$ - ресурс навчального часу для підготовки $i$-ї категорії спеціалістів $(i=\overline{1,4}) ; \quad c_{i}(i=\overline{1,4})$ вартість 1 години занять із спеціалістами $i$-ї категорії; змінні $x_{i}$ - цілі невід'ємні.

Відповідно до попередньо проведених обчислень [2-3], з урахуванням показників $\kappa \approx 1,33$ (18) та

$$
\lambda=0,00042
$$
залежність

$x_{i}=x_{\text {іплан. }} \geq\left[-\frac{\ln \left(1-E_{\text {i потр }}\right)}{\lambda}\right]^{\frac{1}{\kappa}}$

(8) для $i$-х спеціа-

льностей [2-3] можна записати як:

$$
\begin{aligned}
& x_{1} \geq\left[-\frac{\ln \left(1-E_{1 \text { nотр }}\right)}{\lambda}\right]^{\frac{1}{\kappa}}=\left[-\frac{\ln \left(1-E_{1 \text { nomp }}\right)}{0,0002}\right]^{0,77} ; \\
& x_{2} \geq\left[-\frac{\ln \left(1-E_{2 \text { nomp }}\right)}{\lambda}\right]^{\frac{1}{\kappa}}=\left[-\frac{\ln \left(1-E_{2 \text { nomp }}\right)}{0,0002}\right]^{0,77} ;(4) \\
& x_{3} \geq\left[-\frac{\ln \left(1-E_{3 \text { nomp }}\right)}{\lambda}\right]^{\frac{1}{\kappa}}=\left[-\frac{\ln \left(1-E_{3 \text { nomp }}\right)}{0,0002}\right]^{0,77} ;
\end{aligned}
$$

$x_{4} \geq\left[-\frac{\ln \left(1-E_{4 \text { nотр }}\right)}{\lambda}\right]^{\frac{1}{\kappa}}=\left[-\frac{\ln \left(1-E_{4 \text { nomp }}\right)}{0,0002}\right]^{0,77}$, де $\lambda>0$ - перший параметр функціональної залежності $E\left(x_{i}\right)$ - деяка постійна, що характеризує загальноосвітній рівень підготовки особового складу, попередньо досягнутий рівень навченості тощо; $\kappa \geq 1$ - другий параметр функціональної залежності $E\left(x_{i}\right)$ - показник ступеня (цілий чи дробовий): за $\kappa=1$ неперервний розподіл імовірностей Вейбула збігається 3 експоненціальним; за $\kappa=2$ розподіл Вейбула перетворюється у розподіл Релея (двомірний розподіл випадкової величини $\tilde{x}$ за нормальним законом); за $\kappa>3,5$ розподіл Вейбула (відповідно до центральної граничної теореми теорії ймовірностей) збігається 3 нормальним законом розподілу [23]. Оскільки цільова функція та умови-обмеження лінійні відносно змінних, наведена задача належить до задач лінійного цілочисельного програмування, які розв'язуються однозначно за умов-обмежень (23). Розв'язання цієї задачі пропонується здійснювати 3 використанням симплекс метода зі штучним базисом ( $M$-метода). Слід зазначити, що $M$-метод використовується у тих випадках, коли виникають труднощі у знаходженні опорного плану вихідної задачі лінійного програмування в канонічній формі. Іншими словами, сутність $M$-метода полягає в застосуванні симплекс-метода до так званої $M$-задачі, яка отримується із вихідної задачі шляхом додавання до лівої частини системи рівнянь в канонічній формі вихідної задачі лінійного програмування таких штучних одиничних векторів із відповідними невід'ємними штучними змінними, щоб знов отримана матриця включала систему одиничних лінійнонезалежних векторів. Наприклад, в лінійну форму вихідної задачі добавляється у випадку ії максимізації доданок, що являє собою добуток числа $(-M)$ на суму штучних змінних, де $M$ - достатньо велике позитивне число. У разі застосування до задачі симплекс-метода оцінки $\Delta_{j}$ залежатимуть “від букви

$M^{\prime}$. Для порівняння оцінок потрібно пам'ятати, що $M$ - достатньо велике позитивне число, тому із базису будуть виводитися в першу чергу штучні змінні. $\Delta_{j}$. Загальну послідовність такого розв'язання (стисло) викладено нижче.

Відповідно до попередніх обчислень [2-3], приймемо умову, за якої $c_{1}=50$ грн, $c_{2}=60$ грн, $c_{3}=$ $65 г$ гн, $c_{4}=70 г р н ; E_{1 \text { nотр }}=0,8, E_{2 \text { nотр }}=0,9$, $E_{3 \text { потр }}=0,85, E_{4 \text { потр }}=0,91$. Ураховуючи, що умови-обмеження $g_{j}(j=\overline{1, m})$ (2-3) задані у стандартній формі, перейдемо до системи обмежень в основній формі, для чого віднімемо від лівих частин нерівнос- 
тей (4) деякі невід’ємні величини, які мають назву додаткових змінних $x_{5}, x_{6}, x_{7}, x_{8}$. Тоді, цільова функція (1) за умов-обмежень (2-3) запишеться так:

$$
\begin{aligned}
& \min C=c_{1} \cdot x_{1}+c_{2} \cdot x_{2}+c_{3} \cdot x_{3}+c_{4} \cdot x_{4}+\ldots .+ \\
& +c_{i} \cdot x_{i}+0 \cdot x_{5}+0 \cdot x_{6}+0 \cdot x_{7}+0 \cdot x_{8} \ldots+0 \cdot x_{i} .
\end{aligned}
$$

3 урахуванням $x_{i}=x_{\text {пллан. }} \geq\left[-\frac{\ln \left(1-E_{\text {i потр }}\right)}{\lambda}\right]^{\frac{1}{\kappa}}$

(8) та (18), (19) [2-3] отримаємо:

$$
\begin{aligned}
& x_{1}-x_{5} \geq\left[-\frac{\ln \left(1-E_{1 \text { nomp }}\right)}{0,0002}\right]^{0,77}=1017 \\
& x_{2}-x_{6} \geq\left[-\frac{\ln \left(1-E_{2 \text { nomp }}\right)}{0,0002}\right]^{0,77}=1340 \\
& x_{3}-x_{7} \geq\left[-\frac{\ln \left(1-E_{3 \text { nomp }}\right)}{0,0002}\right]^{0,77}=1154 ; \\
& x_{4}-x_{8} \geq\left[-\frac{\ln \left(1-E_{4 \text { nomp }}\right)}{0,0002}\right]^{0,77}=1387,
\end{aligned}
$$

де змінні $x_{i}(i=\overline{1,8})$ - цілі невід'ємні. Проте в додатково уведених змінних $x_{5}, x_{6}, x_{7}, x_{8}$ відсутній (невід'ємний) одиничний базис, а використання одиничного (невід'ємного) базису в змінних $x_{1}, x_{2}, x_{3}, x_{4}$ дає нульове рішення, що є неприйнятним. У такому випадку $M$-метод передбачає додавання штучних змінних $x_{n+1}$, а також деякого великого позитивного числа $M$ (оскільки відшукується мінімум ЦФ). Тобто, поряд із раніше введеними додатковими змінними $x_{5}, x_{6}, x_{7}, x_{8}$ вводяться деякі невід'ємні штучні (фіктивні) змінні $x_{9}, x_{10}, x_{11}, x_{12}$, унаслідок чого область допустимих розв'язків задачі розширюється, отримується розширена задача лінійного цілочисельного програмування з обраною системою обмежень ( $M$-задача), яка матиме вигляд:

$$
\begin{gathered}
\min C=c_{1} \cdot x_{1}+c_{2} \cdot x_{2}+c_{3} \cdot x_{3}+c_{4} \cdot x_{4}+\ldots+ \\
+c_{i} \cdot x_{i}+0 \cdot x_{5}+0 \cdot x_{6}+0 \cdot x_{7}+0 \cdot x_{8} \ldots+0 \cdot x_{i}+ \\
+M\left(x_{9}+x_{10}+x_{11}+x_{12}+\ldots+x_{i}\right)
\end{gathered}
$$

за умов-обмежень (2-3). Тоді (6) можна записати у вигляді:

$$
\begin{gathered}
x_{1}-x_{5}+1 \cdot x_{9}+0 \cdot x_{10}+0 \cdot x_{11}+0 \cdot x_{12}=1017 \\
x_{2}-x_{6}+0 \cdot x_{9}+1 \cdot x_{10}+0 \cdot x_{11}+0 \cdot x_{12}=1340 ; \\
x_{3}-x_{7}+0 \cdot x_{9}+0 \cdot x_{10}+1 \cdot x_{11}+0 \cdot x_{12}=1154 ; \\
x_{4}-x_{8}+0 \cdot x_{9}+0 \cdot x_{10}+0 \cdot x_{11}+1 \cdot x_{12}=1387 ; \\
M>x_{9}+x_{10}, x_{11}, x_{12},+\ldots+x_{i} .
\end{gathered}
$$

Розв'язання розширеної задачі здійснюється за відомим алгоритмом обчислень 3 використанням симплекс таблиць (табл. 1-5). Оцінкові рядки цих таблиць поділені на дві частини-рядки: в $(m+2)$-му рядку записують коефіцієнти з $M$, а в $(m+1)$-му - ті, що не містять $M$. Так, у табл. 1 в індексному (оціночному) рядку найбільшим позитивним числом (оскільки розв'язується задача на мінімум) буде $M-50$, що визначає дозвільний стовпець $\bar{A}_{1}\left(x_{1}\right)$. Розділивши координати вектора $\bar{B}$ у стовпці вільних членів на позитивні елементи дозвільного стовпця $\bar{A}_{1}\left(x_{1}\right)$, обираємо найменше значення з цих відношень, яке дорівнюватиме 1017/1, що й визначить дозвільний рядок $\bar{A} 9\left(x_{9}\right)$. Максимальним позитивним числом в індексному рядку табл. 2 є $M-60$, а дозвільним стовпцем буде вектор $\bar{A}_{2}\left(x_{2}\right)$. Розділимо координати вектора $\bar{B}$ у стовпці вільних членів на елементи 3 тими самими знаками дозвільного стовпця $\bar{A}_{2}\left(x_{2}\right)$.

Виберемо найменше значення з цих відношень, яке дорівнюватиме 1340/1. Це значення визначить дозвільний рядок $\bar{A}_{10}\left(x_{10}\right)$. Із табл. 2 бачимо, що значення ЦФ, яке рівне $F=3881 M+50850$, зменшилося порівняно з попереднім $F=4898 M$ (табл. 1). Однак в індексному рядку є позитивні числа $M-60$, $M-65, M-70$, а отже, мінімум ЦФ ще не досягнутий, тому здійснюється перехід до чергової симплекстаблиці (табл. 3). Із табл. 3 бачимо, що значення ЦФ, яке дорівнює $F=2541 M+131250$, зменшилося порівняно $з$ попереднім значенням $F=3881 M+$ 50850 (табл. 2), однак в індексному рядку також $є$ позитивні числа $M-5, M-70$, а отже, мінімум ЦФ ще не досягнутий. Тому, виникає потреба у переході до чергових симплекс-таблиць (табл. 4-5). В індексному рядку останньої табл. 5 вже немає позитивних елементів, отже, мінімум ЦФ досягнутий і він дорівнює $F=303350$ грн у точці 3 координатами: $x_{1}=$ 1017 год; $x_{2}=1340$ год; $x_{3}=1154$ год; $x_{4}=1387$ год. Значення $F=303350$ грн отримується 3 (5):

$$
\begin{gathered}
C=c_{1} \cdot x_{1}+c_{2} \cdot x_{2}+c_{3} \cdot x_{3}+c_{4} \cdot x_{4}= \\
=50 \cdot 1017+60 \cdot 1340+65 \cdot 1154+70 \cdot 1387= \\
=303350 \text { грн. }
\end{gathered}
$$

\section{Висновки}

Отримані результати розв'язання задачі лінійного цілочисельного програмування, що полягала у відшуканні значень $n$ змінних $x_{1}, x_{2}, x_{3}, x_{4} \ldots, \cdot x_{n}$, які б доставляли екстремум ЦФ $C=\sum_{i=1}^{n} c_{i} \cdot x_{i}$ за критерієм мінімуму фінансових затрат. Отримані результати забезпечують досягнення рівня навченості спеціалістів певної категорії (профілю) не нижче потрібного (заданого). Проте розв'язання наведеної у статті задачі оптимізації не передбачало обчислення досяжного рівня підготовки з'єднання (частини) в цілому. 
预

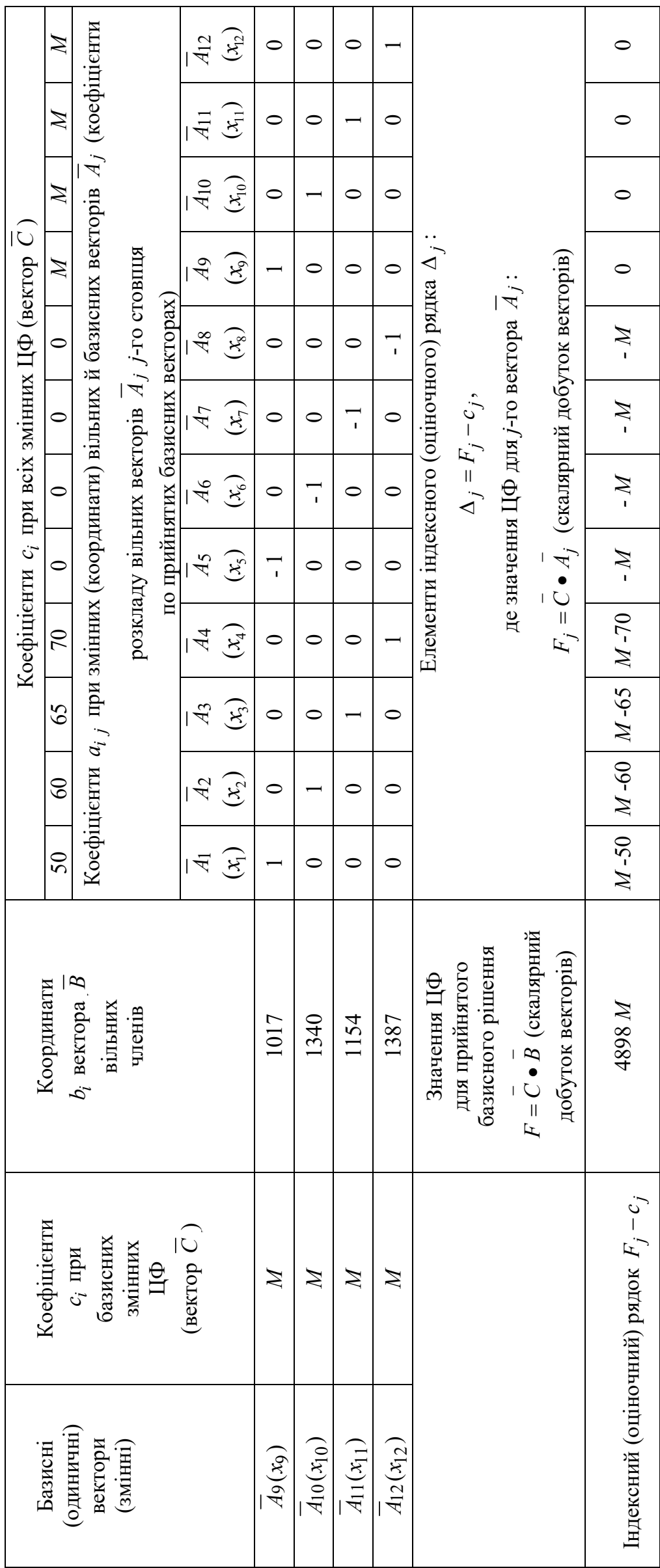

!пиговц-энәгшиио ноґь й-? 
를

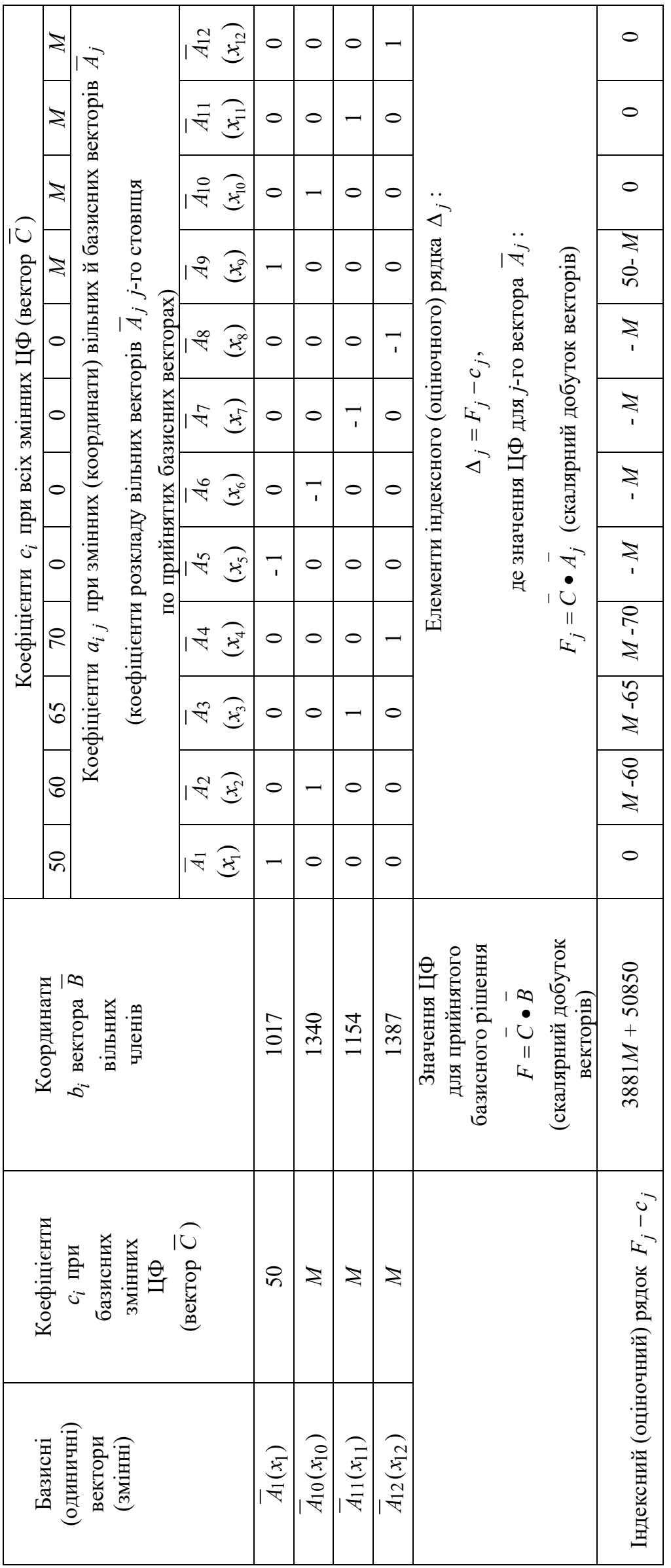

!пиговц-энәгшиио яоґь й-! 
产

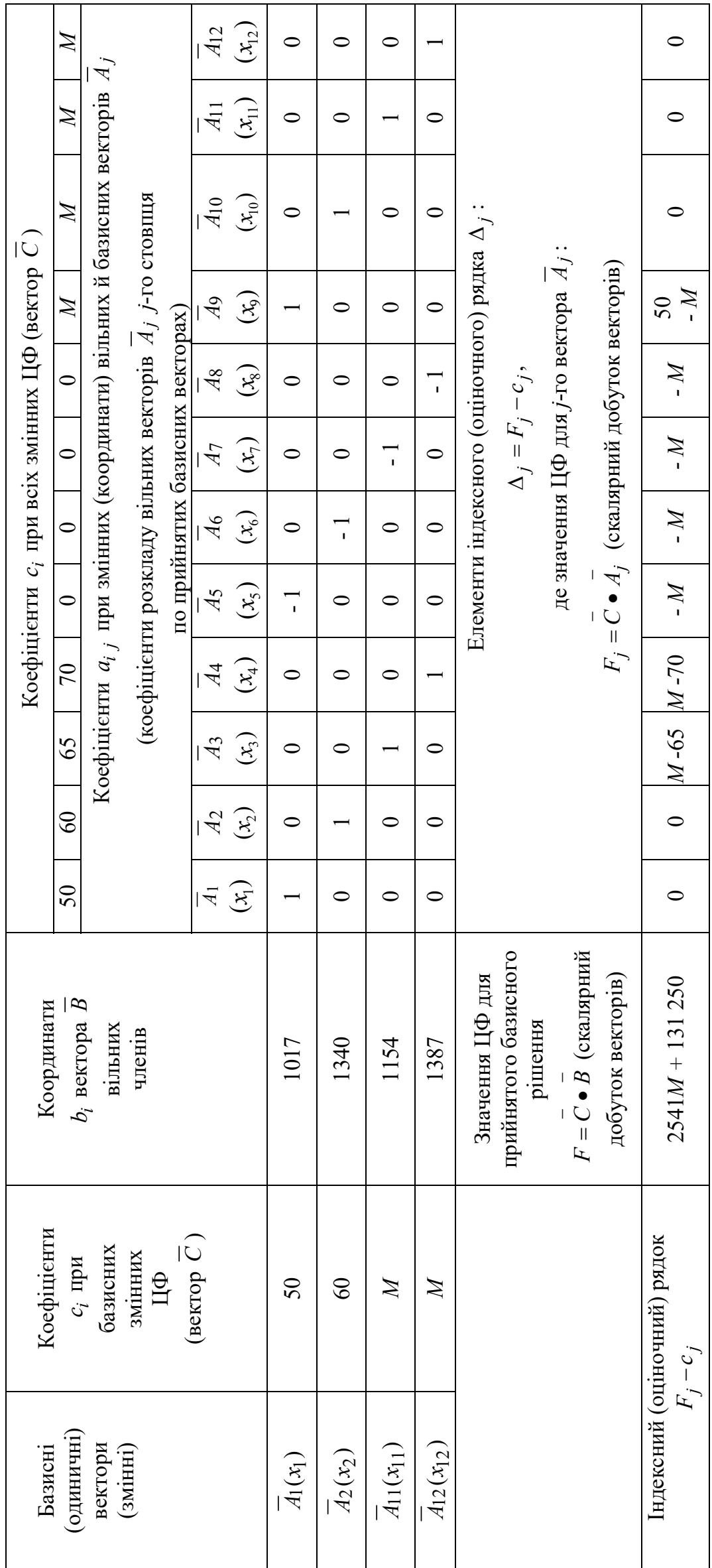

!ุигgец-энәгшиио ногь й-? 


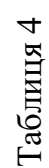

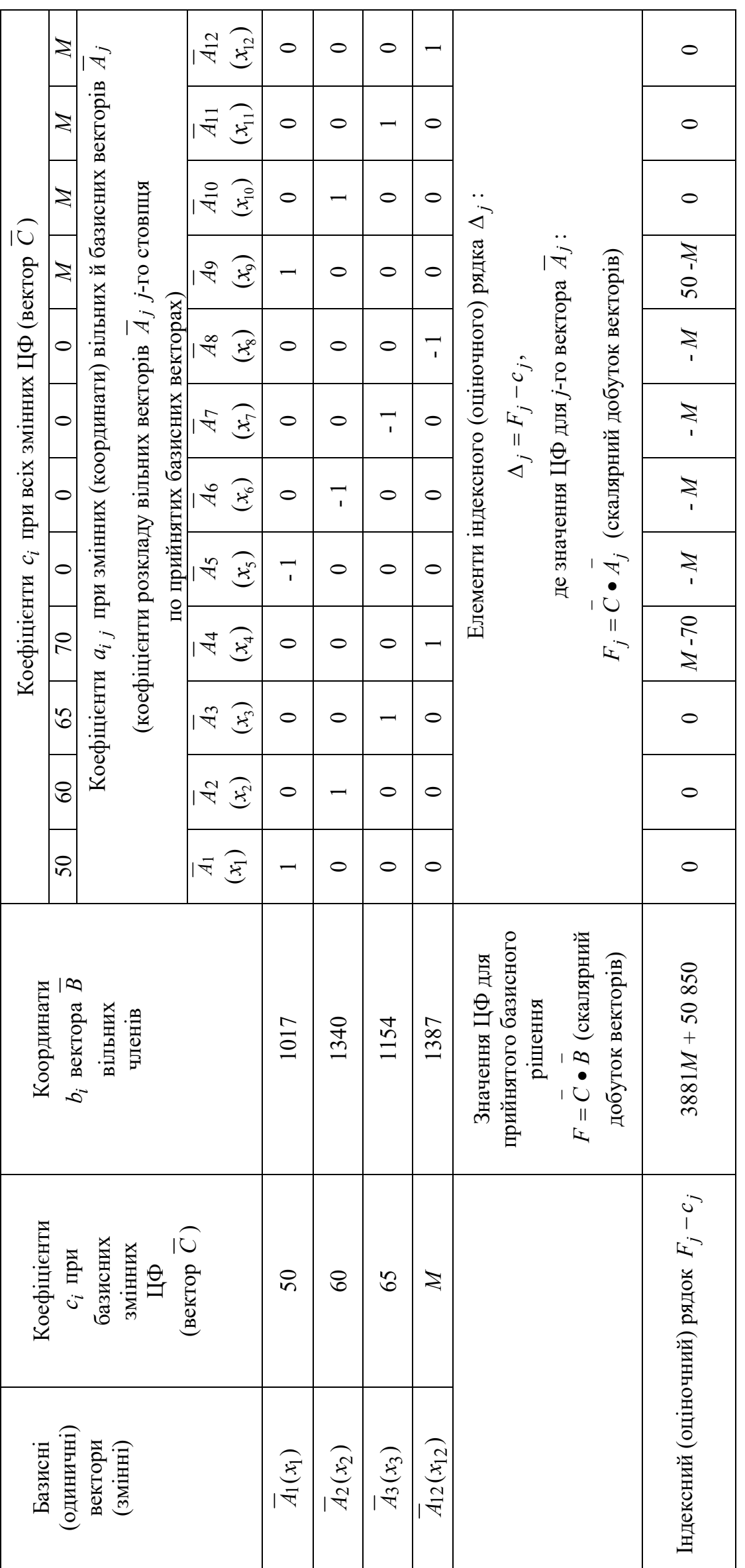

!пигоец-эмәгшииэ моґвd й-? 
n

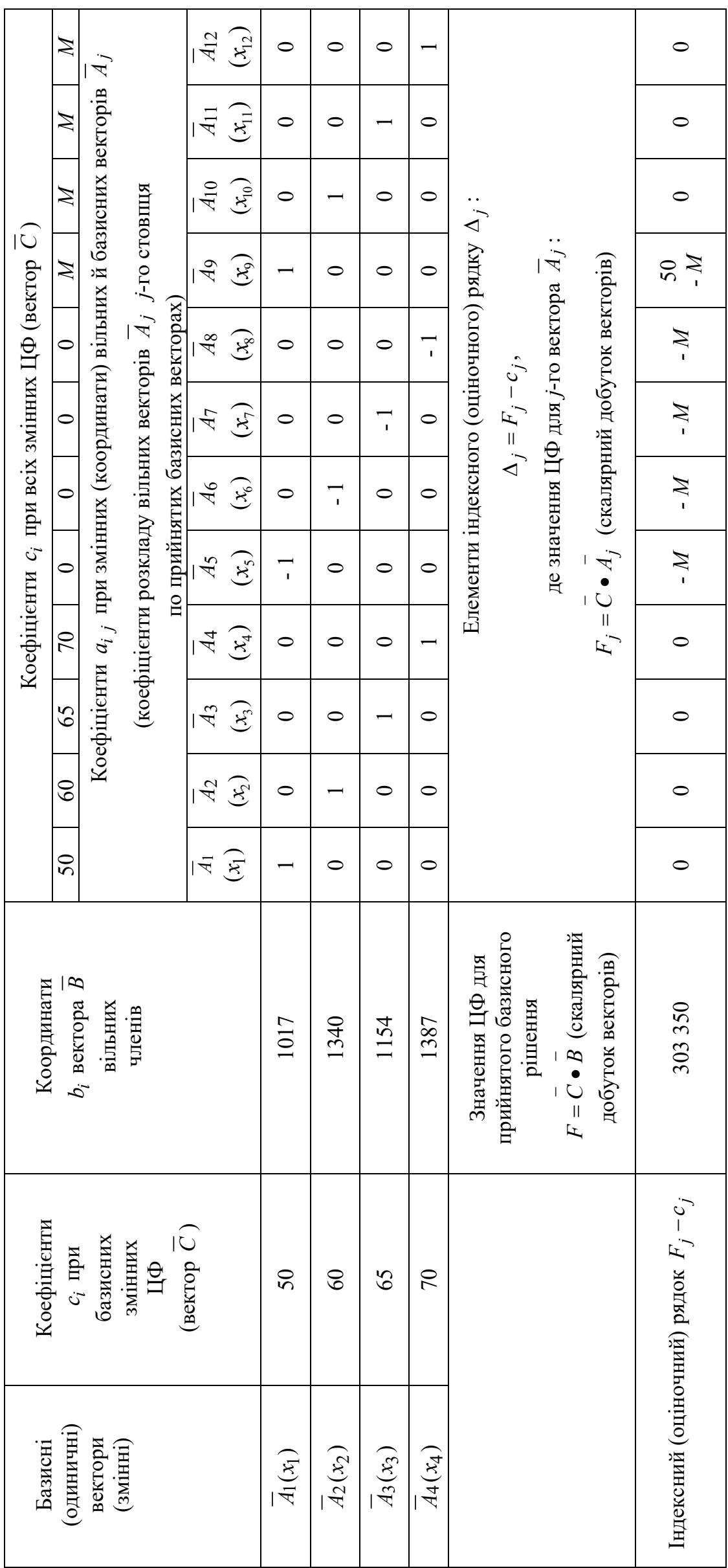

!пиговь-эяәгшииэ яоґь й-! 
Зважаючи на це, на думку авторів, перспективами подальших досліджень $є$ постановка та розв'язання більш складної задачі (нелінійного програмування), яка б, на відміну від викладеної, за відомих рівнів навченості спеціалістів певної категорії (профілю) та з урахуванням важливості (внес- ку) $\alpha$ того або іншого підрозділу роду військ у боєздатність з'єднання (частини), дозволяла визначати ресурс навчального часу $x_{i}(i=\overline{1,4})$, потрібний для досягнення заданого рівня підготовки як підрозділів родів військ, так і з’єднання (частини) в цілому.

\section{Список літератури}

1. Математичні основи теорії утримання військ за ступенем їх готовності: моногр. / І.С. Романченко, В.О. Шуєнкін, Г.А. Саковський, С.В. Годзь. - Київ: ЦНДІ ЗС України, 2019. - 220 с.

2. Годзь С.В. Математична модель визначення загального обсягу навчальних годин комплексної програми бойової підготовки військового формування типу з'єднання (частина) будь-якого ступеня готовності / С.В. Годзь, В.М. Можаровський // Системи обробки інформації. - 2020. - № 2 (161). - С. 47-58. https://orcid.org/10.30748/soi.2020.161.06.

3. Годзь С.В. Обгрунтування загального обсягу навчальних годин комплексної програми бойової підготовки військового формування типу з'єднання (частина) будь-якого ступеня готовності / С.В. Годзь // Труди університету: зб. наук. пр. НУО України ім. Івана Черняховського. - Київ, 2020. - № 2(58).

4. Можаровський В.М. Ключові аспекти методологічних основ розроблення комплексних програм бойової підготовки військових формувань сил оборони держави / В.М. Можаровський, С.В. Годзь // Збірник наукових праць ХНУПС. - 2019. - Вип. 4(62). - С. 7-17. https://doi.org/10.30748/zhups.2019.62.01.

5. Можаровський В.М. Методологічні основи розроблення комплексних програм бойової підготовки військових формувань сил оборони держави / В.М. Можаровський, С.В. Годзь, Г.А. Саковський // Збірник наукових праць ЦНДІ ЗС України. - 2019. - № 4 (90). - С. 68-81.

6. Можаровський В.М. Математична модель обгрунтування оптимального бойового складу збройних сил держави 3 позицій теорії відверненого збитку та з урахуванням економічних чинників / В.М. Можаровський, С.В. Годзь // Кібернетика і системний аналіз: міжн. наук.-теорет. журн. Інститут кібернетики ім. В.М. Глушкова НАН України. - Київ, 2018. Том 54. - № 5. - (ISSN 1019-5262): SCOPUS. C. 150-159.

7. Mozharovskyi V. General approaches to the substantiation of combat staff of the Armed Forces depending on militaryeconomic capabilities of the state / V.Mozharovskyi, S. Hodz // Baltic Journal of Economic Studies. - 2019. - Vol. 5. - No. 5. P. 100-109. https://doi.org/10.30525/2256-0742/2019-5-5-100-109.

8. Шуєнкін В.О. Функціональна залежність рівня навченості спеціалістів різних категорій частини (з’єднання) від кількості виділених на їх підготовку навчальних годин / В.О. Шуєнкін, С.В. Годзь, М.Я. Максименко // Збірник наукових праць ЦНДІ ЗС України. - 2018. - № 4(86). - С. 77-90.

9. Можаровський В.М. Аналіз існуючих методик оцінювання ефективності планування бойової підготовки та рівня навченості військових формувань сил оборони держави / В.М. Можаровський, С.В. Годзь, Г.А. Саковський // Зб. наук. пр. ЦНДІ ЗС України. - 2019. - № 3 (89). - С. 77-90.

10. Годзь С.В. Обгрунтування періодичності проведення навчальних зборів із військовозобов'язаними з урахуванням лінійної та нелінійної залежності швидкості втрачання ними раніше набутих знань, умінь і навичок / С.В. Годзь // Труди університету: зб. наук. пр. НУО України ім. І. Черняховського. - Київ, 2020. - № 1 (57). - С. 125-142.

\section{References}

1. Romanchenko, I.S., Shuenkin, V.O., Sakovskyi, G.A. and Godz, S.V. (2019), "Matematychni osnovy teoriji utrymannia vijsjk za stupenem jikh gotovnosty: monoghr." [Mathematical foundations of the theory of the maintenance of troops by their degree of readiness: monograph], Central Scientific and Research Institute of the Armed Forces of Ukraine, Kyiv, 220 p.

2. Godz, S.V. and, Mozharovskyi, V.M. (2020), "Matematichna model viznachennya zagalnogo obsyagu navchalnih godin kompleksnoyi programi bojovoyi pidgotovki vijskovogo formuvannya tipu z'yednannya (chastina) bud-yakogo stupenya gotovnosti" [Mathematical model for determining the total amount of training hours of a comprehensive program of combat training of military formations of the type of connection (part) of any degree of readiness], Information Processing Systems, No 2(161), pp. 47-58. https://orcid.org/10.30748/soi.2020.161.06.

3. Godz, S.V. (2020), "Obgruntuvannya zagalnogo obsyagu navchalnih godin kompleksnoyi programi bojovoyi pidgotovki vijskovogo formuvannya tipu z'yednannya (chastina) bud-yakogo stupenya gotovnosti” [Substantiation of the total amount of training hours of the complex program of combat training of military formation of the type of connection (part) of any degree of readiness], Works of the University: Collection of Scientific Works of NDU named after Ivan Cherniakhovskyi, No. 2(58).

4. Mozharovskyi, V.M. and Godz, S.V. (2019), "Kljuchovi aspekty metodologhichnykh osnov rozroblennja kompleksnykh proghram bojovoji pidghotovky vijsjkovykh formuvanj syl oborony derzhavy" [Key aspects of methodological bases of development of complex programs of combat training of military formations of state defense forces], Scientific Works of Kharkiv National Air Force University, No. 4(62), pp. 7-17. https://doi.org/10.30748/zhups.2019.62.01.

5. Mozharovskyi, V.M., Godz, S.V. and Sakovsjkyj, Gh.A. (2019), "Metodologhichni osnovy rozroblennja kompleksnykh proghram bojovoji pidghotovky vijsjkovykh formuvanj syl oborony derzhavy" [Methodological bases of development of complex programs of combat training of military formations of the state defense forces], Collection of Scienctific Works of Central Research Institute of the Armed Forces of Ukraine, No. 4(90), pp. 68-81. 
6. Mozharovskyi, V.M. and Godz, S.V. (2018), "Matematichna model obgruntuvannya optimalnogo bojovogo skladu zbrojnih sil derzhavi z pozicij teoriyi vidvernenogo zbitku ta z urahuvannyam ekonomichnih chinnikiv" [Mathematical model of substantiation of the optimal combat composition of the armed forces of the state from the standpoint of the theory of averted damage and taking into account economic factors], Cybernetics and systems analysis: int. scientific-theoretical magazine Institute of Cybernetics named after V.M. Glushkov, Vol. 54, No. 5, Kyiv, pp. 150-159.

7. Mozharovskyi, V.M. and Godz, S.V. (2019), General approaches to the substantiation of combat staff of the Armed Forces depending on military-economic capabilities of the state, Baltic Journal of Economic Studies, Vol. 5, No. 5, pp. $100-109$. https://doi.org/10.30525/2256-0742/2019-5-5-100-109.

8. Shuenkin, V.A., Godz, S.V. and Maksimenko, M.Ia. (2018), "Funkcionaljna zalezhnistj rivnja navchenosti specialistiv riznykh kateghorij chastyny (z'jednannja) vid kiljkosti vydilenykh na jikh pidghotovku navchaljnykh ghodyn” [Functional dependence of the level of training of specialists of different categories of a unit (connection) on the number of training hours allocated for their preparation], Collection of Scienctific Works of Central Research Institute of the Armed Forces of Ukraine, No. 4(86), pp. 77-90.

9. Mozharovskyi, V.M., Godz, S.V. and Sakovskyi, G.A. (2019), “Analiz isnujuchykh metodyk ocinjuvannja efektyvnosti planuvannja bojovoji pidghotovky ta rivnja navchenosti vijsjkovykh formuvanj syl oborony derzhavy" [Analysis of existing methods of assessing the effectiveness of planning of combat training and the level of training of military formations of the defense forces of the state], Collection of Scientific Works of the Central Scientific and Research Institute of the Armed Forces of Ukraine, No. 3(89), pp. 77-90.

10. Godz, S.V. (2020), “Obgruntuvannya periodichnosti provedennya navchalnih zboriv iz vijskovozobov'yazanimi z urahuvannyam linijnoyi ta nelinijnoyi zalezhnosti shvidkosti vtrachannya nimi ranishe nabutih znan, umin i navichok" [Substantiation of the Periodicity of Training Meetings with the Servicemen, Taking into account the Linear and Nonlinear Dependence of the Speed of the Loss of Previously Acquired Knowledge and Skills], Works of the University: Collection of Scientific Works of NDU named after Ivan Cherniakhovskyi, No. 1(57), pp. 125-142.

\section{Відомості про авторів:}

\section{Годзь Сергій Віталійович}

кандидат військових наук старший дослідник старший науковий співробітник Центрального науково-дослідного інституту Збройних Сил України, Київ, Україна

https://orcid.org/0000-0002-7860-2330

\author{
Можаровський Володимир Миколайович \\ доктор військових наук старший дослідник \\ провідний науковий співробітник Центрального \\ науково-дослідного інституту Збройних Сил України, \\ Київ, Україна \\ https://orcid.org/0000-0003-3542-5407
}

Пантюшенко Роман Валерійович старший науковий співробітник Центрального науково-дослідного інституту Збройних Сил України, Київ, Україна

https://orcid.org/0000-0002-9301-9389
Information about the authors:

\author{
Sergii Godz \\ Candidate of Military Sciences Senior Research \\ of the Central Scientific and Research Institute \\ of the Armed Forces of Ukraine, \\ Kyiv, Ukraine \\ https://orcid.org/0000-0002-7860-2330
}

\author{
Volodymyr Mozharovskyi \\ Doctor of Military Sciences Senior Research \\ Lead Research of the Central Scientific \\ and Research Institute of the Armed Forces of Ukraine, \\ Kyiv, Ukraine \\ https://orcid.org/0000-0003-3542-5407
}

\author{
Roman Pantiushenko \\ Senior Research of the Central Scientific \\ and Research Institute of the Armed Forces of Ukraine, \\ Kyiv, Ukraine \\ https://orcid.org/0000-0002-9301-9389
}

\section{ОПТИМИЗАЦИЯ РАСПРЕДЕЛЕНИЯ УЧЕБНЫХ ЧАСОВ КОМПЛЕКСНОЙ ПРОГРАММЫ БОЕВОЙ ПОДГОТОВКИ СОЕДИНЕНИЯ (ЧАСТИ) МЕЖДУ СПЕЦИАЛИСТАМИ (ПОДРАЗДЕЛЕНИЯМИ) РОДОВ ВОЙСК}

С.В. Годзь, В.Н. Можаровский, Р.В. Пантюшенко

Поиск возможных путей повышения эффективности боевой подготовки (БП) воинских формирований, как неотъемлемой составляющей их боеспособности, всегда был и остается приоритетным направлением деятельности и первоочередной задачей командиров и штабов всех уровней. По мнению авторов, одним из возможных путей обеспечения нужного уровня обученности воинских формирований является разработка и внедрение в практику их БП принципиально нового нормативного документа - Комплексной программы боевой подготовки воинского формирования типа соединение (часть) сил обороны (КПБП). Разработка КПБП должна быть всесторонне, в том числе научно, обоснованной. Однако в существующих методиках оченки эффективности БП воинских формирований, в том числе ее планирования, используются совершенно разные методы исследования зависимости уровня обученности специалистов определенной категории (профиля) и подразделений родов войск от количества учебных часов, которые в течение определенного периода выделяются на их подготовку. Существующие методики не позволяют осуществлять рациональное 
(оптимальное) распределение учебных часов между специалистами (подразделениями) родов войск для достижения заданного уровня обученности соединения (части) в целом. Также эти методики не учитывают (учитывают частично) ограничения по финансированию мероприятий БП и не предусматривают комплексного подхода к обеспечению необходимого уровня боеспособности соединений (частей).

По мнению авторов, в настоящее время возникла необходимость в использовании методического аппарата, который бы, учитывая уровень финансирования БП, позволял определять оптимальное количество учебных часов, а также осуществлять их оптимальное распределение между специалистами (подразделениями) родов войск для достижения заданного уровня обученности соединения (части) в иелом. В предлагаемой статье изложено основное содержание задачи оптимизации распределения учебных часов КПБП между специалистами (подразделениями) родов войск для достижения заданного уровня их обученности (линейный вариант). Статья является логическим продолжением предыдущих публикаций по данному направлению исследования.

Ключевые слова: боевая подготовка, планирование боевой подготовки, комплексная программа боевой подготовки, математическая модель, метод исследования, задача оптимизации.

\section{THE OPTIMIZING THE DISTRIBUTION OF THE EDUCATIONAL HOURS OF AN INTEGRATED PROGRAM OF THE COMBAT PREPARATION OF A FORMATION (UNIT) BETWEEN SPECIALISTS (UNITS) OF THE BRANCHES}

S. Godz, V. Mozharovskyi, R. Pantiushenko

The search for possible ways to increase the effectiveness of combat training (CT) of military formations, as an integral component of their combat effectiveness, has always been and remains a priority area of activity and a priority task for commanders and staffs at all levels. According to the authors, one of the possible ways to ensure the necessary level of training of military units is to develop and put into practice their CT with a fundamentally new regulatory document - a Comprehensive combat training program for a military formation such as a unit of the defence forces (CCTP). The development of the CCTP should be comprehensive, including scientifically substantiated. However, the existing methods for evaluating the effectiveness of CT of military units, including its planning, use completely different methods to study the dependence of the training level of specialists of a certain category (profile) and units of military branches on the number of training hours that are allocated for their training during a certain period. Existing methods do not allow a rational (optimal) distribution of training hours between specialists (units) of military branches to achieve a given level of training of the compound (unit) as a whole. Also, these methods do not take into account (partially take into account) the restrictions on financing CT events and do not provide an integrated approach to ensuring the necessary level of combat readiness of formations (units).

According to the authors, now there is a need to use the methodological apparatus, which, taking into account the level of CT funding, would allow us to determine the optimal number of training hours, as well as their optimal distribution between specialists (units) of military branches to achieve a given level of compound (unit) training generally. The proposed article is outlined the main content of the task of optimizing the teaching hours distribution of the CCTP between specialists (units) of military branches to achieve a given level of training (linear variant). The article is a logical continuation of previous publications in this area of research.

Keywords: combat training, combat training planning, comprehensive combat training program, mathematical model, research method, optimization problem. 